\title{
HUBUNGAN FASILITAS SANITASI DASAR DENGAN TINGKAT KEPADATAN LALAT PADA RUMAH MAKAN DI KECAMATAN TANJUNG KARANG PUSAT KOTA BANDAR LAMPUNG
}

\author{
Ulfa Andriani ${ }^{1)}$
}

\begin{abstract}
Abstrak
Lalat merupakan vektor penyakit dan keberadaannya menjadi indikasi kebersihan yang kurang baik di suatu tempat. Sanitasi dasar diperlukan untuk menciptakan lingkungan rumah makan yang bersih dan sehat, serta memenuhi syarat kesehatan.Tujuan dari penelitian ini adalah untuk mengetahui hubungan fasilitas sanitasi dasar dengan tingkat kepadatan lalat pada rumah makan Kecamatan Tanjung Karang Pusat, Kota Bandar Lampung.

Penelitian ini menggunakan survey analitik dengan rancangan cross sectional yang dilaksanakan pada bulan April 2019. Populasi adalah seluruh rumah makan yang ada di Kecamatan Tanjung Karang Pusat Kota Bandar Lampung. Tidak dilakukan pengambilan sampel, sehingga seluruh populasi dimasukkan ke dalam penelitian. Pengumpulan data dilakukan dengan observasi menggunakan checklist, dan pengukuran kepadatan lalat menggunakan fly grill.

Hasil penelitian mendapatkan hubungan signifikan antara tingkat kepadatan lalat dengan tempat pembuangan sampah ( $\mathrm{p}$-value=0,000), dan saluran pembuangan air limbah ( $\mathrm{p}$-value 0,002 ). Namun, tidak menunjukkan hubungandengan sarana air bersih $(\mathrm{p}$-value $=0,362)$, dan tempat pembuangan tinja ( $\mathrm{p}$-value $=0,221)$. Perlu peningkatan upaya sanitasi rumah makan, pengetahuan dan keterampilan pengelola, serta pengawasan dari instansi terkait.
\end{abstract}

Kata Kunci : Kepadatan Lalat, sampah, SPAL, air bersih, jamban

${ }^{1)}$ Alumni Program Studi D4 Kesehatan Lingkungan Politeknik Kesehatan Tanjungkarang

\section{PENDAHULUAN}

Lalat merupakan kelompok serangga pengganggu dan sekaligus sebagai vektor penular penyakit. Pada saat ini dijumpai tidak kurang dari 60.000 sampai dengan 100.000 spesies lalat. Tidak semua spesies perlu diawasi, karena beberapa di antaranya tidak membahayakan bagi manusia. Beberapa jenis lalat yang berlu diawasi adalah rumah (Musca domestica), lalat kandang (Stomoxys calcitrans), lalat hijau (Phenisia), lalat daging (Sarcoplaga), dan lalat kecil (Fannia) (Azwar, 1995 dalam Jannah, 2006).

Dipandang dari sudut kesehatan, kepadatan lalat merupakan masalah yang penting. Semua bagian tubuh lalat bisa berperan sebagai alat penular penyakit, yaitu badan, bulu pada tangan dan kaki serta faces, dan muntahannya. Penyakit-penyakit yang ditularkan oleh lalat antara lain disentri, kolera, diare, dan lainnya yang berkaitan dengan kondisi sanitasi lingkungan yang buruk. Lalat biasanya hidup pada tempat yang kotor. Selain terdapat sumber makanan, juga digunakan untuk berkembang biak. Dengan demikian tingginya populasi lalat dapat dipakai sebagai indikator keadaan sanitasi dalam lingkungan masyarakat. Praktik kebersihan dan sanitasi yang buruk dapat menciptakan kondisi yang tidak sehat dan dapat menimbulkan penyakit. Sanitasi yang perlu diperhatikan adalah sanitasi tempat umum, karena umum merupakan tempat kegiatan bagi masyarakat sehingga berpeluang besar dalam penularan dan penyebaran penyakit (UNICEF, 2012 dalam Kumala, 2016).

Rumah makan dan restoran dalam menjalankan usahanya harus memenuhi persyaratan higiene sanitasi. Menurut Kemenkes RI (2003), persyaratan higiene sanitasi rumah makan dan restoran terdiri dari persyaratan lokasi dan bangunan, fasilitas sanitasi seperti air bersih dapur, ruang makan, gudang makanan, bahan makanan dan makanan jadi, pengolahan makanan, tempat penyimpanan bahan makanan 
dan makanan jadi, penyajian makanan, dan peralatan yang digunakan.

Berdasarkan Survei awal yang telah dilakukan di beberapa rumah makan di Kecamatan Tanjung Karang Pusat Kota Bandar Lampung, masih banyak dijumpai lalat yang berada di rumah makan, terutama di sekitar dapur, lantai, meja makan dan di sekitar tempat sampah. Jumlah lalat yang dijumpai dari beberapa rumah makan berkisar antara 5-10 ekor, masuk dalam kategori padat sehingga harus dilakukan tindakan pengamanan dan pengendalian. Penelitian bertujuan mengetahui tingkat kepadatan lalat dan hubungannya dengan fasilitas sanitasi di rumah makan di Kecamatan Tanjung Karang Pusat, Kota Bandar Lampung.

\section{METODE}

Jenis Penelitian ini adalah deskriptif analitik, menggunakan rancangan cross sectional. Populasi penelitian adalah seluruh rumah makan yang berada di Kecamatan Tanjung Karang Pusat, sebanyak 50 rumah makan. Tidak dilakukan pengambilan sampel, sehingga seluruh populasi dimasukkan ke dalam penelitian.

Observasi sarana sanitasi dilakukan terhadap sarana air bersih, tempat pembuangan tinja/toilet, tempat pembuangan sampah, dan saluran pembuangan air limbah (SPAL). Pengukuran kepadatan lalat pada setiap rumah makan dilakukan pada empat titik, yaitu pada sarana air bersih, tempat pembuangan tinja/toilet, tempat pembuangan sampah dan saluran pembuangan air limbah (SPAL). Pengukuran kepadatan lalat dilakukan selama 30 detik, dan dilakukan pengulangan pengukuran 10 kali pada setiap titik pengamatan. Dari 10 kali pengamatan, diambil lima nilai tertinggi.

Untuk mendapatkan data yang valid, dilakukan tiga kali pengukuran kepadatan lalat pada setiap lokasi (rumah makan), yaitu pada pukul (13.00-13.30), (14.30-15.00), dan (16.0016.30). Pemilihan waktu pengukuran mengikuti jam padat kunjungan rumah makan. Pengukuran menggunakan fly grill, tally counter, dan stopwatch. Data yang terkumpul selanjutnya diolah dan dianalisis secara univariat dan bivariat menggunakan uji Chi Square pada alpha $=0,05$.

\section{HASIL}

\section{Kepadatan Lalat}

Menurut Permenkes No.50 tahun 2017, kepadatan lalat 0-2 ekor dikategorikan rendah; kategori sedang, jika kepadatan lalat 3-5 ekor; kategori tinggi, jika memiliki kepadatan lalat 620; dan sangat tinggi, jika kepadatan lalatnya lebih dari 21.

Berdasarkan hasil pengukuran kepadatan lalat (Tabel 1) di sarana air bersih, sebanyak 34 (68\%) rumah makan masuk kategori sedang, dan $16(32 \%)$ rumah makan masuk kategori rendah. Pada titik pengukuran di tempat pembuangan tinja/toilet, sebanyak 7 (14\%) rumah makan masuk kategori tinggi, 23 (46\%) masuk kategori sedang, dan $20(40 \%)$ rumah makan masuk kategori rendah.

Tabel 1. Hasil Pengukuran Kepadatan Lalat

\begin{tabular}{lcc}
\hline $\begin{array}{c}\text { Titik Pengukuran dan Tingkat } \\
\text { Kepadatan lalat }\end{array}$ & Jumlah lalat & Persentase \\
\hline Pada Sarana Air Bersih & 34 & 68 \\
$\quad$ Sedang & 16 & 32 \\
$\quad$ Rendah & 7 & 14 \\
Pada Tempat Pembuangan Tinja & 23 & 46 \\
$\quad$ Tinggi & 20 & 40 \\
Sedang & & \\
Rendah & 28 & 56 \\
Pada Tempat Pembuangan Sampah & 11 & 22 \\
Tinggi & 11 & 22 \\
Sedang & & 36 \\
Rendah & 18 & 40 \\
Pada Tempat Pembuangan Air Limbah & 20 & 24 \\
$\quad$ Tinggi & 12 & \\
Sedang & & \\
Rendah & & \\
\hline
\end{tabular}


Pada titik pengukuran di tempat pembuangan sampah, sebanyak 28 (56\%) rumah makan masuk kategori tinggi, 11 (22\%) masuk kategori sedang, dan 11 (22\%) rumah makan masuk kategori rendah. Sedangkan hasil pengukuran di tempat pembuangan air limbah, sebanyak 18 (36\%) rumah makan masuk kategori tinggi, 20 (40\%) masuk kategori sedang, dan 12 (24\%) masuk dalam kategori rendah.

Berdasarkan hasil pada setiap titik pengukuran pada Tabel 1, dilakukan pengelompokan rumah makan berdasarkan kepadatan lalat. Hasil pengelompokan mendapatkan sebanyak 34 (68\%) rumah makan masuk dalam kategori sedang, dan sebanyak 16 (32\%) rumah makan masuk dalam kategori tinggi.

\section{Sarana Sanitasi}

Tabel 2. Keadaan Sarana Sanitasi Pada Rumah Makan

\begin{tabular}{lll}
\hline \multicolumn{1}{c}{ Jenis Sarana Sanitasi } & N & $\%$ \\
\hline Sanitasi Air Bersih & 39 & 78 \\
$\quad$ Memenuhi Syarat & 11 & 22 \\
$\quad$ Tidak Memenuhi Syarat & & \\
Tempat Pembuangan Tinja & 37 & 74 \\
$\quad$ Memenuhi Syarat & 13 & 26 \\
$\quad$ Tidak Memenuhi Syarat & 10 & 24 \\
Tempat Pembuangan Sampah & 40 & 76 \\
$\quad$ Memenuhi Syarat & & \\
$\quad$ Tidak Memenuhi Syarat & 17 & 34 \\
Saluran Pembuangan air limbah & 33 & 66 \\
$\quad$ Memenuhi Syarat & \multicolumn{2}{|c}{} \\
$\quad$ Tidak Memenuhi Syarat &
\end{tabular}

\section{Hubungan Sarana Sanitasi dengan Tingkat Kepadatan Lalat}

Hasil analisis pada Tabel 3 menjelaskan, sebagian besar $(90,9 \%)$ rumah makan dengan sarana air bersih yang tidak memenuhi syarat, memiliki kepadatan lalat kategori tinggi. Demikian pula pada rumah makan dengan sarana air bersih memenuhi syarat, sebagian besar juga memiliki kepadatan lalat kategori tinggi $(28,2 \%)$. Hasil analisis statistik tidak menunjukkan hubungan antara sarana air bersih dengan kepadatan lalat ( $\mathrm{p}$-value $>0,05$ ).

Mayoritas rumah makan (92,3\%) dengan sarana pembuangan tinja yang tidak memenuhi syarat, memiliki kepadatan lalat kategori tinggi. Demikian pula pada rumah makan dengan sarana pembuangan tinja memenuhi syarat, sebagian besar juga memiliki kepadatan lalat kategori tinggi $(70,3 \%)$. Hasil analisis statistik tidak menunjukkan hubungan antara sarana
Observasi sarana sanitasi rumah makan mengacu pada Keputusan Menteri Kesehatan RI Nomor 1098/Menkes/SK/VII/2003, tentang persyaratan higiene sanitasi pada rumah makan dan restoran. Hasil observasi mendapatkan rumah makan dengan sarana air bersih memenuhi syarat sebanyak $78 \%$, dan tidak memenuhi syarat sebanyak $22 \%$. Sebanyak $74 \%$ rumah makan memiliki tempat pembuangan tinja yang memenuhi syarat, dan $26 \%$ yang tidak memenuhi syarat kesehatan.

Penelitian juga mendapatkan sebanyak 24\% rumah makan telah memiliki tempat pembuangan sampah yang memenuhi syarat, namun sebanyak $76 \%$ tidak memenuhi syarat. Pada SPAL, sebanyak 34\% rumah makan telah memiliki SPAL yang memenuhi syarat, namun $66 \%$ tidak memenuhi syarat (Tabel 2). pembuangan tinja dengan kepadatan lalat ( $\mathrm{p}-$ value $>0,05)$.

Pada penilaian sarana pembuangan sampah, mayoritas rumah makan $(90,0 \%)$ dengan sarana pembuangan sampah tidak memenuhi syarat, memiliki kepadatan lalat kategori tinggi. Sedangkan rumah makan dengan sarana pembuangan sampah memenuhi syarat, sebagian besar memiliki kepadatan lalat kategori sedang $(80,0 \%)$. Hasil analisis statistik menunjukkan hubungan signifikan antara sarana pembuangan sampah dengan kepadatan lalat ( $\mathrm{p}$-value $<0,05$ ).

Mayoritas rumah makan $(90,9 \%)$ dengan SPAL tidak memenuhi syarat, memiliki kepadatan lalat kategori tinggi. Sedangkan rumah makan dengan SPAL memenuhi syarat, sebagian besar memiliki kepadatan lalat kategori sedang (52,1\%). Hasil analisis statistik menunjukkan hubungan signifikan antara SPAL dengan kepadatan lalat ( $\mathrm{p}$-value $<0,05$ ). 
Tabel 3. Hubungan Sarana Sanitasi dengan Tingkat Kepadatan Lalat

\begin{tabular}{lcccccc}
\hline \multirow{2}{*}{ Variabel } & \multicolumn{2}{c}{ Tinggi } & \multicolumn{2}{c}{ Sedang } & \multirow{2}{*}{$\mathrm{N}$} & \multirow{2}{*}{ p-value } \\
\cline { 2 - 5 } & $\mathrm{n}$ & $\%$ & $\mathrm{n}$ & $\%$ & & \\
\hline Sarana air bersih & 10 & 90,9 & 1 & 9,1 & 11 & 0,257 \\
$\quad$ Tidak memenuhi syarat & 28 & 71,8 & 11 & 28,2 & 39 & \\
$\quad$ Memenuhi syarat & & & & & & \\
$\quad$ Sarana pembuangan tinja & 12 & 92,3 & 1 & 7,7 & 13 & 0.257 \\
$\quad$ Tidak memenuhi syarat & 26 & 70,3 & 11 & 29,7 & 37 & \\
$\quad$ Memenuhi syarat & & & & & & \\
Sarana pembuangan sampah & 36 & 90,0 & 4 & 10,0 & 40 & 0,0001 \\
$\quad$ Tidak memenuhi syarat & 2 & 20,0 & 8 & 80,0 & 10 & \\
$\quad$ Memenuhi syarat & & & & & & \\
SPAL & 30 & 90,9 & 3 & 9,1 & 33 & 0,0001 \\
$\quad$ Tidak memenuhi syarat & 8 & 47,1 & 9 & 52,9 & 17 & \\
$\quad$ Memenuhi syarat & & & & &
\end{tabular}

\section{PEMBAHASAN}

\section{Sarana Air Bersih}

Hasil penelitian mendapatkan bahwa berdasarkan kepadatan lalat di sarana air bersih, sebanyak $34(68 \%)$ rumah makan masuk kategori sedang, dan 16 (32\%) rumah makan masuk kategori rendah. Sedangkan Hasil observasi mendapatkan sebanyak $78 \%$ rumah makan memiliki sarana air bersih yang memenuhi syarat, dan $22 \%$ tidak memenuhi syarat. Namun hasil uji statistik tidak menunjukkan hubungan antara kedua variabel (p-value $>0,05$ ).

Hasil tersebut relevan dengan penelitian Kasiono, (2016) yang membuktikan tidak ditemukannya hubungan antara sarana sanitasi air bersih dengan tingkat kepadatan lalat. Menurut Depkes RI (2007), kelembaban yang optimum untuk aktifitas dan perkembangbiakan lalat adalah $90 \%$. Lama kehidupan lalat sangat tergantung pada makanan, air dan temperatur. Sarana Air bersih yang ada di rumah makan Kecamatan Tanjung Karang Pusat memiliki sarana air bersih yang sudah tertutup sehingga dapat menahan masuknya lalat.

Lalat suka hidup di tempat yang kotor, misalnya pada kotoran manusia, kotoran hewan, dan bahan organik yang membusuk dan lembab. Lalat juga tertarik pada bau-bauan yang busuk, serta bau dari makanan atau minuman (Azwar, 2007 dalam Wibowo, 2017). Air bersih mempunyai kandungan zat organik yang kecil, meski demikian lalat kadangkala hinggap di sarana air bersih. Supaya tidak menimbulkan gangguan kesehatan, sarana air bersih sebaiknya ditutup dan pemilik rumah makan bisa melakukan pencegahan lalat secara biologi dengan cara memanfaatkan bau atau aroma beberapa tanaman seperti cengkeh, daun sirih, pandan, lavender dan tembakau.

\section{Tempat Pembuangan Tinja}

Hasil pengukuran di tempat pembuangan tinja/toilet, sebanyak 7 (14\%) rumah makan masuk kategori tinggi, 23 (46\%) masuk kategori sedang, dan $20(40 \%)$ rumah makan masuk kategori rendah. Hasil observasi mendapatkan sebanyak $74 \%$ rumah makan memiliki tempat pembuangan tinja yang memenuhi syarat, dan $26 \%$ yang tidak memenuhi syarat kesehatan. Hasil ini menunjukkan bahwa sarana pembuangan tinja di rumah makan telah memenuhi syarat kesehatan (Kemenkes RI, 2003), yaitu tidak berhubungan langsung dengan dapur atau ruang makan, tersedia sabun dan alat pengering, tersedia septitank dan jamban berbentuk leher angsa, lantai kedap air dan tidak licin, pembungan tinja tertutup dan tidak menimbulkan bau.

Pada Tabel 3 terlihat bahwa hasil uji statistik tidak menunjukkan hubungan antara kedua variabel ( $p$-value $>0,05$ ). Hasil ini sesuai dengan penelitian Kasiono, (2016) yang membuktikan bahwa tidak ada hubungan antara tempat pembuangan tinja dengan tingkat kepadatan lalat ( $p$ value $=0,631$ ). Sarana pembuangan tinja (jamban) telah memenuhi persyaratan jamban sehat yakni menggunakan jenis jamban leher angsa, tidak menimbulkan bau $\left(\mathrm{H}_{2} \mathrm{~S}\right)$ dari zat organik, bau yang timbul hanya dari kandungan amoniak pada urine $\left(\mathrm{NH}_{3}\right)$, sehingga tidak ada lalat yang hinggap pada sarana pembuangan tinja. Berdasarkan prilaku lalat, pada tahap pradewasa lalat memilih habitat yang cukup banyak bahan organik (Mangoli, 2016). 
Bahaya terhadap kesehatan yang dapat ditimbulkan akibat pembuangan kotoran secara tidak baik adalah pencemaran tanah, pencemaran air, dan perkembangbiakan lalat. Sementara itu, penyakit-penyakit yang dapat terjadi akibat keadaan diatas antara lain diare, disentri, kolera, tifoid, penyakit cacing dan beberapa penyakit lainnya. Pembuangan kotoran manusia yang baik merupakan hal yang mendasar bagi keserasian lingkungan (Chandra, 2006 dalam Kasiono 2016). Sebaiknya untuk sarana pembuangan tinja yang tidak memenuhi syarat, harus dilengkapi dengan air yang cukup, tersedia sabun, tidak menimbulkan bau dan mempunyai septitank dan jamban berbentuk leher angsa.

\section{Tempat Pembuangan Sampah}

Hasil pengukuran di tempat pembuangan sampah, sebanyak 28 (56\%) rumah makan masuk kategori tinggi, 11 (22\%) masuk kategori sedang, dan $11(22 \%)$ rumah makan masuk kategori rendah. Berdasarkan penilaian kualitas sarana, sebanyak $24 \%$ rumah makan memiliki tempat pembuangan sampah yang memenuhi syarat, dan $76 \%$ yang tidak memenuhi syarat kesehatan. Hasil analisis statistik menunjukkan hubungan signifikan antara sarana pembuangan sampah dengan kepadatan lalat ( $\mathrm{p}$-value $<0,05$ ).

Hasil penelitian relevan dengan Mangoli (2016) yang membuktikan adanya hubungan antara sarana pembuangan sampah dengan tingkat kepadatan lalat (p-value 0,000). Adanya hubungan antara kedua variabel karena pengelolaan sampah di rumah makan masih belum memenuhi syarat kesehatan. Sebagian besar rumah makan menggunakan tempat sampah yang terbuat dari bahan yang tidak kedap air dan terbuka, tidak kuat dan mudah bocor, sampah yang tidak dibuang dalam waktu 24 jam, Tempat pembuangan sampah yang menimbulkan bau, basah dan berserakan akan mengundang datangnya lalat karena ada zat organik seperti (protein, lemak, karbohidrat, amoniak) yang membusuk. Hal ini menunjukkan masih rendahnya tingkat kepedulian pihak pengelola rumah makan dalam menjaga kebersihan.

Umumnya lalat berkembang biak di luar hunian manusia, pada bahan yang telah membusuk dan berbau, seperti vegetasi yang membusuk, kotoran hewan, sampah dan sejenisnya. Lalat suka hidup di tempat yang kotor, seperti pada kotoran manusia, kotoran hewan, dan sampah. Lalat tertarik pada bau- bauan yang busuk, serta bau dari makanan atau minuman (Hadi, 2006). Berdasarkan prilaku lalat, pada tahap pradewasa, lalat memilih habitat yang cukup banyak bahan organik yang sedang mengalami dekomposisi, misalnya sampah organik yang basah oleh sebab itu populasi lalat lebih banyak berada di tempat sampah. Jika kepadatan lalat tinggi di sebuah rumah makan, maka lalat dapat mencemari makanan dari kuman yang dibawanya, serta akan mengganggu kenyamanan pengunjung (Mangoli, 2016).

Pengelolaan sampah yang kurang baik akan menjadikan sampah sebagai tempat pekembangbiakan vektor penyakit, seperti lalat atau tikus. Selain itu, sampah yang membusuk akan menimbulkan bau, sehingga dapat mengundang vektor dan tikus. Sampah memiliki kuman penyebab penyakit yang dapat menyebar ke orang melalui lalat (Rejeki, 2015).

Sebaiknya tempat pembuangan sampah harus memenuhi persyaratan seperti dibuat dari bahan kedap air, tidak mudah berkarat, mempunyai tutup, dan memakai kantong plastik khusus untuk sisa-sisa bahan makanan dan makanan yang cepet membusuk. Selain itu, sebaiknya tempat sampah tersedia pada setiap tempat/ruang yang memproduksi sampah, dan diangkut minimal setiap 24 jam.

Pengendalian lalat dewasa juga dapat dilakukan memakai kertas perekat lalat, perangkap lampu (light trap), memasang kasa anti pada lubang ventilasi dan jendela, serta penggunaan pestisida.

\section{Tempat Pembuangan Air Limbah}

Hasil pengukuran kepadatan lalat di tempat pembuangan air limbah (Tabel 1), mendapatkan sebanyak 18 (36\%) rumah makan masuk kategori tinggi, 20 (40\%) masuk kategori sedang, dan 12 (24\%) masuk dalam kategori rendah. Sedangkan hasil berdasarkan penilaian SPAL, sebanyak 34\% rumah makan telah memiliki SPAL yang memenuhi syarat, namun $66 \%$ tidak memenuhi syarat (Tabel 2). Hasil analisis statistik menunjukkan hubungan signifikan antara SPAL dengan kepadatan lalat (p-value $<0,05$ ). Hasil penelitian sesuai dengan Kasiono (2016) yang membuktikan adanya hubungan signifikan antara sarana pembuangan air limbah dengan tingkat kepadatan lalat ( $\mathrm{p}$ value $=0,000$ ).

Tingginya kepadatan lalat pada SPAL rumah makan karena SPAL pada rumah makan tidak memenuhi syarat kesehatan, yaitu air limbah 
tidak mengalir lancar, saljuran terbuka dan tidak kedap air, menimbulkan bau. Lalat tertarik dan akan mendatangi tempat yang berbau karena terdapat sumber makanan, dan sebagai tempat perkembangbiakan (Kasiono, 2016).

Perlu dilakukan perbaikan SPAL rumah makan sesuai dengan Kepmenkes RI (2003), yaitu sistem pembuangan air limbah harus baik, saluran terbuat dari bahan kedap air, tidak menjadi sumber pencemar, dan menggunakan saluran tertutup. Manurut Chandra (2006), SPAL yang baik seharusnya tidak mengakibatkan kontaminasi terhadap sumbersumber air minum, tidak menimbulkan pencemaran pada flora dan fauna yang hidup di air, tidak dihinggapi oleh vektor atau serangga yang menyebabkan penyakit, tidak terbuka, dan tidak menimbulkan bau.

\section{KESIMPULAN}

Hasil pengukuran kepadatan lalat di rumah makan Kecamatan Tanjungkarang Pusat, Kota Bandar Lampung mendapatkan sebanyak 34 (68\%) rumah makan masuk dalam kategori sedang, dan sebanyak 16 (32\%) rumah makan masuk dalam kategori tinggi. Sedangkan berdasarkan penilaian kualitas fasilitas sanitasi, sebagian besar tempat pembuangan sampah dan air limbah (SPAL) belum memenuhi syarat kesehatan. Hasil analisis statistik membuktikan hubungan signifikan antara kepadatan lalat dengan pembuangan sampah dan air limbah. Pihak pengelola rumah makan diharapkan dapat melakukan perbaikan sistem pembuangan sampah dan air limbah. Pengawasan secara kontinyu dari Dinas Kesehatan, Pariwisata, dan Lingkungan Hidup perlu ditingkatkan untuk menghindari terjadinya masalah kesehatan, lingkungan, dan estetika.

\section{DAFTAR PUSTAKA}

Chandra, B. 2006. Pengantar Kesehatan Lingkungan, Jakarta.

Jannah, Dewi Nur. 2006. Perbedaan Kepadatan Lalat pada Berbagai Warna Fly Grill, Studi di TPS Pasar beras Bendul Merisi,

Surabaya. Skripsi, FKM Unair, Surabaya.

Kasiono, Umboh, Boky, 2016. Hubungan Antara Sanitasi Dasar dengan Tingkat Kepadatan Lalat Di Rumah Makan Pasar Tuminting, Manado

(medkesfkm.unsrat.ac.id/wpcontent/uploads/2016/...JURNAL-AnnisaM.-Kasiono.pd.)

Kemenkes RI. 2003. Keputusan Menteri Kesehatan Republik Indonesia Nomor 1098/MENKES/SK/VII/2003 tentang, Persyaratan Hygiene Sanitasi Rumah Makan dan Restoran.

Kumala. 2016. Gambaran Kondisi Sanitasi Kantin Dan Tingkat KepadatanLalat Pada Sekolah Dasar Di Wilayah Kerja Puskesmas Kedung mundu Tembalang, Semarang (lib.unnes.ac.id/28152/1/6411412178.pdf)

Mangoli, Pinontoan, Boky. 2016. Hubungan Sanitasi Dasar Dengan Tingkat Kepadatan Lalat di Rumah Makan Pasar Pinasungkalan Karombasan, Manado (https://ejournalhealth.com/index.php/ikma s/article/viewFile/90/8)

Notoadmodjo, Soekidjo. 2011. Metodelogi Penelitian kesehatan. Jakarta: Rineka Cipta

Peraturan Menteri Kesehatan Lingkungan Republik Indonesia Nomor 50 Tahun 2017 Tentang Standar Baku Mutu Kesehatan Lingkungan Dan Persyaratn Kesehatan Untuk Vektor Dan Binatang Pembawa Penyakit Serta Pengendaliannya.

Rejeki, S. 2015. Sanitasi Hygiene dan k3 (Kesehatan dan Keselamatan Kerja) Bandung: Rekayasa Sains

Hadi, Upik Kusumawati; Sigit, Singgih Harsoyo; 2006. Hama Pemukiman Indonesia, Bogor, 473 halaman.

Wibowo, Satria Tri. 2017. Skripsi Hubungan Keadaan Konstruksi, Jenis, Dan Jarak wadah sampah Dengan Kepadatan Lalat Pada Kantin Sekolah Dasar Di Kecamatan Way Jepara Lampung Timur. 